\title{
Inhibitory Effect of (-)-myrtenol alone and in combination with antifungal agents on
}

\section{Candida spp.}

Efeito inibitório do (-)-myrtenol sozinho e em combinação com agentes antifúngicos sobre Candida spp.

Efecto inhibidor del (-)-myrtenol solo y en combinación con agentes antifúngicos sobre Candida

spp.

Bruno Bezerra Cavalcanti

ORCID: https://orcid.org/0000-0002-7091-4241

Federal University of Paraiba, Brazil

E-mail: brunobc@gmail.com

Hermes Diniz-Neto

ORCID: https://orcid.org/0000-0003-2878-1737

Federal University of Paraiba, Brazil

E-mail: hermes.dn@hotmail.com

Walicyranison Plinio da Silva-Rocha

ORCID: https://orcid.org/0000-0003-0639-2781

Federal University of Paraiba, Brazil

E-mail: wps@ academico.ufpb.br

Edeltrudes de Oliveira Lima

ORCID: https://orcid.org/0000-0002-9547-0886

Federal University of Paraiba, Brazil

E-mail: edelolima@yahoo.com.br

José Maria Barbosa Filho

ORCID: https://orcid.org/0000-0002-9567-4096 Federal University of Paraiba, Brazil

E-mail: barbosa.ufpb@gmail.com

Ricardo Dias de Castro

ORCID: https://orcid.org/0000-0001-7986-7376

Federal University of Paraiba, Brazil

E-mail: rcastro@ccs.ufpb.br

Fabio Correia Sampaio

ORCID: https://orcid.org/0000-0003-2870-5742

Federal University of Paraiba, Brazil

E-mail: fcsampa@gmail.com

Felipe Queiroga Sarmento Guerra

ORCID: https://orcid.org/0000-0003-2057-4821

Federal University of Paraiba, Brazil

E-mail: fqsg@ @academico.ufpb.br

\begin{abstract}
The aim of this study was to examine the effects of (-)-myrtenol alone and combined with antifungal agents against Candida spp. The Minimum Inhibitory Concentration (MIC) and Minimum Fungicidal Concentration of (-)-myrtenol and fluconazole against $C$. albicans and $C$. parapsilosis strains was obtained using CLSI guidelines. Combination of (-)-myrtenol with antifungal drugs was determined by checkboard test. The (-) myrtenol showed MIC ranging from 256 to $512 \mu \mathrm{g} / \mathrm{mL}$ against both species assay. And the MFC was $512 \mu \mathrm{g} / \mathrm{mL}$, demonstrated nature fungicidal (MFC/MIC < 4). In addition, combination of antifungal agents (amphotericin B and fluconazole) and (-) myrtenol showed synergistic and additive effects on strains assays. Based on these results, the present study demonstrates that () myrtenol showed strong fungicide activity against Candida spp. In addition, Combination of antifungal agents and () myrtenol reduces the effective concentrations of both the agents with synergistic to additive effects. Therefore, (-) myrtenol has potential to be developed into an antifungal agent.
\end{abstract}

Keywords: Monoterpenes; Antifungal activity; Natural products; Alternative therapy.

\section{Resumo}

O objetivo deste estudo foi analisar os efeitos do (-)-mirtenol sozinho e combinado com agentes antifúngicos frente Candida spp. A Concentração Inibitória Mínima (CIM) e a Concentração Fungicida Mínima de (-) - mirtenol e 
fluconazol frente as cepas de C. albicans e C. parapsilosis foram obtidas usando as diretrizes de CLSI. A combinação de (-) - mirtenol com drogas antifúngicas foi determinada pelo teste de checkboard. (-) mirtenol apresentou CIM variando de 256 a $512 \mu \mathrm{g} / \mathrm{mL}$ frente ambas as espécies. E o MFC foi de $512 \mu \mathrm{g} / \mathrm{mL}$, demonstrado natureza fungicida (MFC / MIC <4). Além disso, a combinação de agentes antifúngicos (anfotericina B e fluconazol) e (-) mirtenol frente as cepas ensaiadas apresentou efeitos sinérgicos e aditivos. Com base nesses resultados, o presente estudo demonstra que (-) mirtenol apresentou forte atividade fungicida contra Candida spp. Além disso, a combinação de agentes antifúngicos e (-) mirtenol demonstraram efeitos sinérgicos a aditivos, com redução da CIM de ambos agentes. Portanto, o (-) mirtenol tem potencial para ser desenvolvido como um agente antifúngico.

Palavras-chave: Monoterpeno; Atividade antifúngica; Produto natural; Terapia alternativa.

\section{Resumen}

El objetivo de este estudio fue analizar los efectos del (-)-myrtenol solo y combinado con agentes antifúngicos contra Candida spp. La Concentración Inhibitoria Mínima (MIC) y la Concentración Fungicida Mínima de (-) - myrtenol y fluconazol contra cepas de C. albicans y C. parapsilosis se obtuvieron utilizando las pautas de CLSI. La combinación de (-) - myrtenol con fármacos antimicóticos se determinó mediante la prueba del tablero de ajedrez. El (-) myrtenol mostró una CIM que varió de 256 a $512 \mu \mathrm{g} / \mathrm{mL}$ contra ambas especies. Y la MFC fue de $512 \mu \mathrm{g} / \mathrm{mL}$, demostró naturaleza fungicida (MFC / MIC <4). Además, la combinación de agentes antifúngicos (anfotericina B y fluconazol) y (-) myrtenol contra las cepas probadas mostró efectos sinérgicos y aditivos. Con base en estos resultados, el presente estudio demuestra que el (-) myrtenol tenía una fuerte actividad fungicida contra Candida spp. Además, la combinación de agentes antifúngicos y (-) myrtenol mostró efectos sinérgicos con los aditivos, con una reducción de la CMI de ambos agentes. Por lo tanto, el (-) myrtenol tiene el potencial de desarrollarse como un agente antifúngico.

Palabras clave: Monoterpeno; Actividad antifúngica; Producto natural; Terapia alternativa.

\section{Introduction}

Fungal infections have achieved considerable importance over the last few decades, especially candidiasis, the most frequent opportunistic fungal infection, caused by strains of the Candida spp. With the development of superficial or problematic infections, such as invasive candidiasis, with a high mortality rate (Ben-Ami, 2018).

Invasive candidiasis affecting mainly immunocompromised patients in intensive care units (ICUs). Among the different Candida species isolated, $C$. albicans is the most common isolated, followed by non-albicans species such as $C$. glabrata, C. parapsilosis, C. krusei, C. tropicalis and the most recent C. auris, pathogen-resistant multidrug emerging (JefferySmith et al., 2018; Pappas et al., 2018).

The strategy for the treatment of candidiasis depends on the patient's immune status, location, and severity of the infection, however a lack of rapid diagnostic assay, mainly invasive candidiasis, normally empiric antifungal therapy was initiated. This approach can lead to the unnecessary use of antifungal agents and promote the emergence of resistance in individuals (Bhattacharya et al., 2020).

A major factor that contributes to the high levels of morbidity and mortality of fungal diseases is the limited number of antifungal drugs. Currently, there are only three classes of antifungal drugs approved for the treatment of invasive mycoses, echinocandins, polyene and azoles. The efficacy of these agents is compromised by the development of drug resistance in pathogen populations, respective adverse effects and treatment costs (Lee et al., 2020; Wall \& Lopez-Ribot, 2020).

Therefore, it is necessary to search for alternatives to this scenario. Through the development of new drugs that are more effective and have fewer adverse effects or that can be used in combination with current antifungals. One of the main sources of search is natural products and their derivatives, such as bicyclic monoterpene alcohols that have been shown to have several biological effects in the literature. (Nikitina et al., 2021)

(-) Myrtenol is an example of this group with several reported biological effects in literature: angiogenesis (Huang et al., 2021), gastric protector (Viana et al., 2019), anti-bacterial (Cordeiro et al., 2020). Thus, the aim of this study was to examine the effects of myrtenol alone and in combination with antifungal drugs against Candida spp. 


\section{Material and Methods}

\subsection{Type of study}

This is an experimental laboratory study of a quantitative nature (Tacconi, 2018)

\subsection{Microorganisms:}

Candida spp. used in the antifungal assay was obtained from the archival collection of the Federal University of Paraiba Laboratory of Mycology (LM). They included C. albicans (ATCC 76485, LM-117, LM-516, LM-587 and LM-699), and C. parapsilosis (ATCC 22019, LM-439, LM-546, LM-577 and LM- 689). The inoculum preparation was carried out by M27 A2 document (CLSI., 2008)

\subsection{Chemicals}

The product tested was the (-) myrtenol, amphotericin B, Fluconazole and RPMI-1640-L-glutamine (without sodium bicarbonate) obtained by Sigma-Aldrich®, São Paulo, SP, Brazil. Sabouraud dextrose agar (SDA) were purchased from Difco Laboratories (Detroit, MI, USA), culture media were used.

\subsection{Minimum Inhibitory Concentration (MIC) and Minimum fungicide Concentration (CFM)}

The MIC of myrtenol and fluconazole was carried out using the microdilution technique in a microplate containing 96 wells with a U-shaped bottom (ALAMAR ${ }^{\circledR}$ ), described by M27 A2 document (CLSI, 2008), with some modifications. The myrtenol had their test concentrations ranging between $1024 \mu \mathrm{g} / \mathrm{mL}$ and $0.5 \mu \mathrm{g} / \mathrm{mL}$, Fluconazole was used as a positive control in assays at concentrations ranging from 64 to $0.125 \mu \mathrm{g} / \mathrm{mL}$. Tension viability controls, average sterility, DMSO and Tween $80 \%$, solvents used to prepare myrtenol emulsion, were performed simultaneously with the assay. All the tests were performed in duplicate and the plates were incubated at $35 \pm 2{ }^{\circ} \mathrm{C}$ for 24 hours to be conducted later playback. MIC was defined as the lowest concentration of products capable of producing visible inhibition on fungal growth when compared to its control.

The result was expressed by the arithmetic mean of the MICs obtained in the three tests. According to Sartoratto et al., 2004, results is considered strong antifungal activity MIC values between $0.05-0.50 \mathrm{mg} / \mathrm{mL}$, MIC values between 0.6 to 1.50 $\mathrm{mg} / \mathrm{mL}$ are considered moderately active and values MIC higher than $1.50 \mathrm{mg} / \mathrm{mL}$ are related to a weak antifungal activity.

After determination of the MIC, $10 \mu \mathrm{l}$ aliquots of the supernatant from the wells corresponding to the MIC, MIC $\times 2$ and MIC $\times 4$ were subculture in an SDA containing plate, which was then incubated at $37 \circ \mathrm{C}$ for $24-48 \mathrm{~h}$. The MFC was the lowest drug concentration that showed either no growth or fewer than three colonies. All assays were performed in triplicate, and the geometric mean values were calculated. The MFC/MIC ratio was calculated to determine if the substance had fungistatic (MFC/MIC $\geq 4$ ) or fungicidal (MFC/MIC < 4) activity (Siddiqui et al., 2013)

\subsection{Combination study (checkerboard assay)}

The (-) myrtenol was used in combination with fluconazole and amphotericin, following a method described previously Ahmad et al., 2015. (-) Myrtenol was combined with the antifungal drugs in a 1:1 volume ratio to the first row of microtiter plate and were serially diluted. A $100 \mu \mathrm{l}$ of culture inoculum was added into each well and the plates were then incubated at $37{ }^{\circ} \mathrm{C}$ for $24 \mathrm{~h}$, followed by MICs recording as described above. The experiment was performed in triplicate to validate the results. Based on lower additivity zero-interaction theory, combination interaction was calculated by determining the fractional inhibitory concentration index (FIC) indices were calculated as FIC $^{\mathrm{A}}+\mathrm{FIC}^{\mathrm{B}}$, where FIC $^{\mathrm{A}}$ and FIC ${ }^{\mathrm{B}}$ represent the Minimum Concentrations inhibiting the fungal growth for drugs $\mathrm{A}$ and $\mathrm{B}$, respectively:

FICA $=$ MIC ${ }^{\mathrm{A}}$ combination $/ \mathrm{MIC}^{\mathrm{A}}$ alone and $\mathrm{FIC}^{\mathrm{B}}=\mathrm{MIC}^{\mathrm{B}}$ combination/MIC $\mathrm{MI}^{\mathrm{B}}$ alone. A mean FIC index was 
calculated based on the following equation: $\mathrm{FIC}$ index $=$ FIC $^{\mathrm{A}}+$ FIC $^{\mathrm{B}}$.

The interpretation was made as follows: synergistic $(<0.5)$, additivity $(0.5-1$.$) , indifferent (>1)$ or antagonistic $(>4)$ (Ahmad et al., 2015)

\section{Results and Discussion}

The strategy for the treatment of candidiasis depends on the patient's immune status, location, and severity of the infection, however a lack of rapid diagnostic assay, mainly invasive candidiasis, normally empiric antifungal therapy was initiated. This approach can lead to the unnecessary use of antifungal agents and promote the emergence of resistance in individuals (Bhattacharya et al., 2020). Therefore, there is a dire need to discover novel antifungal agents.

The MIC and MFC values are presented in Table 1. The molecule showed inhibitory activity against all tested strains, with a MIC ranging from 256 to $512 \mu \mathrm{g} / \mathrm{mL}$ against both species assay. And the MFC was $512 \mu \mathrm{g} / \mathrm{mL}$, demonstrated nature fungicidal (MFC/MIC < 4) (Siddiqui et al., 2013).

Table 1: MIC and MFC of (-) myrtenol and fluconazole against strains of C. albicans and C. parapsilosis.

\begin{tabular}{|c|c|c|c|c|c|c|c|c|c|}
\hline \multirow{2}{*}{\multicolumn{2}{|c|}{ Microorganisms }} & \multicolumn{4}{|c|}{ (-) Myrtenol } & \multirow{2}{*}{$\begin{array}{c}\text { Flu } \\
\text { MIC }\end{array}$} & \multicolumn{2}{|c|}{ Controls } & \multirow{2}{*}{ Sol } \\
\hline & & MIC & MFC & $\frac{\text { MFC }}{\text { MIC }}$ & Nature activity & & Mo & Ste & \\
\hline \multirow{5}{*}{ 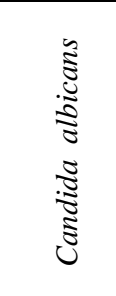 } & ATCC 76485 & 512 & 512 & 1 & Fungicide & $32(\mathrm{R})$ & + & - & + \\
\hline & LM-117 & 512 & 512 & 1 & Fungicide & $08(\mathrm{R})$ & + & - & + \\
\hline & LM-516 & 256 & 512 & 2 & Fungicide & $64(\mathrm{R})$ & + & - & + \\
\hline & LM-587 & 256 & 512 & 2 & Fungicide & $16(\mathrm{R})$ & + & - & + \\
\hline & LM-616 & 256 & 512 & 2 & Fungicide & $08(\mathrm{R})$ & + & - & + \\
\hline \multirow{5}{*}{ 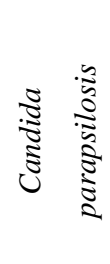 } & ATCC 22019 & 512 & 512 & 1 & Fungicide & $16(\mathrm{R})$ & + & - & + \\
\hline & LM-439 & 512 & 512 & 1 & Fungicide & $32(\mathrm{R})$ & + & - & + \\
\hline & LM-546 & 512 & 512 & 1 & Fungicide & $16(\mathrm{R})$ & + & - & + \\
\hline & LM-689 & 512 & 512 & 1 & Fungicide & $32(\mathrm{R})$ & + & - & + \\
\hline & LM-577 & 512 & 512 & 2 & Fungicide & 64(R) & + & - & + \\
\hline
\end{tabular}

Note: Flu: fluconazole; (R): Resistant (according to CLSI, 2008); Mo: microorganism; Ste: sterility; Sol: RPMI + solvents; +: growth; -: no growth. Source: author himself. Fonte: Autores.

This result showed that the (-) myrtenol has showed strong fungicide activity against Candida spp. with MIC: 512 $\mu \mathrm{g} / \mathrm{mL}$, according criteria marked by Sartoratto et al., 2004. Supporting these results, Nikitina et al., 2021 showed that (-)myrtenol has high antimycotic activity against all tested fungal species (yeast and filamentous fungi), MIC range ( $23.5 \mu \mathrm{g} / \mathrm{mL}$ $-47 \mu \mathrm{g} / \mathrm{mL})$.

The literature data suggest that antifungal activity of (-)-myrtenol, possibly, probably damages the fungal membrane, affecting the change in the functional state of integrin-like proteins, which can lead to disruption of the morphogenesis of the fungal cell (Gomes et al., 2017)

In addition to their inherent antifungal properties, natural products and their derivatives may alter the effects of standard antifungal drugs. The potential benefits of combination therapy include: different mechanisms acting together allow complementary targeting within the fungal cells; expansion of the action spectrum, toxicity reduction due to lower dosage use and lower number of resistant organisms (Chang et al., 2017; Fuentefria et al., 2018). 
In Tables 2 and 3, the results were observed to combinations of the (-) myrtenol with antifungal drugs (amphotericin B and fluconazole) against C. albicans ATCC 76485 and C. parapsilosis ATCC 22019. Additive effect (FIC: 1) was observed for the combinations of (-) myrtenol with fluconazole against C. albicans ATCC 76485. Synergistic effects (FIC: 0.187 and 0.625) were observed for the combinations of (-) myrtenol with amphotericin B against C. albicans ATCC 76485 and $C$. parapsilosis ATCC 22019. The same synergistic effect was observed from the combinations of (-) myrtenol with fluconazole against C. parapsilosis ATCC 22019.

Table 2: MIC of Antifungal drugs and effect of combination with (-) myrtenol against C. albicans ATCC 76485.

\begin{tabular}{lccc}
\hline Antifungal + myrtenol & MIC $(\boldsymbol{\mu g} / \mathbf{m L})$ & $\begin{array}{l}\text { FIC } \\
\text { interaction) }\end{array}$ \\
\hline (-) Myrtenol & 512 & \\
Amphotericin B & 1 & \\
Fluconazole & 32 & \\
(-) Myrtenol/ Amphotericin B & $32 / 0,125$ & 0.187 (Synergism) \\
(-) Myrtenol/ Fluconazole & $256 / 16$ & 1 (Additivity) \\
\hline
\end{tabular}

Note: FIC: Fractional Inhibitory Concentration. MIC: Minimal Concentration Inhibitory. Source: Author himself

Table 3: MIC of Antifungal drugs and effect of combination with (-) myrtenol against C. parapsilosis ATCC 22019.

\begin{tabular}{lccc}
\hline Antifungal + (-) myrtenol & MIC $(\boldsymbol{\mu g} / \mathbf{m L})$ & $\begin{array}{l}\text { FIC } \\
\text { interaction) }\end{array}$ \\
\hline (-) Myrtenol & 512 & \\
Amphotericin B & 1 & \\
Fluconazole & 16 & 0.625 (Synergism) \\
(-) Myrtenol/ Amphotericin B & $64 / 0,5$ & 0.75 (Synergism) \\
(-) Myrtenol/ Fluconazole & $128 / 0,5$ & \\
\hline
\end{tabular}

Note: FIC: Fractional Inhibitory Concentration. MIC: Minimal Concentration Inhibitory. Source: Author himself.

In this study, synergistic and additivity effects were demonstrated when was combinate the (-) myrtenol with the antifungal agents (amphotericin B and fluconazole) against Candida spp., depending on the strain assay, suggesting the (-) myrtenol positively modulated the in vitro action of this drugs, suggesting future pharmacological use as an adjuvant for these drugs.

Several reports have been made concerning different antifungal combinations assayed in vitro and applied in the clinic (Dąbrowska et al., 2021; Fuentefria et al., 2018; Perea et al., 2002; Shaban et al., 2020). However, combinations of the (-) myrtenol with antifungal agents against Candida spp. are reported here for the first time.

\section{Conclusion}

Based on these results, the present study demonstrates that (-) myrtenol showed strong fungicide activity against Candida spp. with MIC $512 \mu \mathrm{g} / \mathrm{ml}$. In addition, Combination of antifungal agents and (-) myrtenol reduces the effective concentrations of both the agents with synergistic to additive effects. Therefore, (-) myrtenol has potential to be developed into an antifungal agent. However, future studies on this product are necessary, such as search to mechanism of action, toxicity tests, aiming their possible application in the clinic or as a source of new antimicrobial compounds. 


\section{Acknowledgments}

These studies were partially funded by National Counsel of Technological and Scientific Development (CNPq).

\section{References}

Ahmad, A., Wani, M. Y., Khan, A., Manzoor, N., \& Molepo, J. (2015). Synergistic Interactions of Eugenol-tosylate and Its Congeners with Fluconazole against Candida albicans. PLOS ONE, 10(12), e0145053. https://doi.org/10.1371/JOURNAL.PONE.0145053

Ben-Ami, R. (2018). Treatment of Invasive Candidiasis: A Narrative Review. Journal of Fungi. 4(97), 4(3), 97. https://doi.org/10.3390/JOF4030097

Bhattacharya, S., Sae-Tia, S., \& Fries, B. C. (2020). Candidiasis and Mechanisms of Antifungal Resistance. 312, 9(6), 312. https://doi.org/10.3390/ANTIBIOTICS9060312

Chang, Y. L., Yu, S. J., Heitman, J., Wellington, M., \& Chen, Y. L. (2017). New facets of antifungal therapy, 8(2), 222-236. https://doi.org/10.1080/21505594.2016.1257457

Clinical and Laboratory Standards Institute. (2008). Reference method for broth dilution antifungal susceptibility testing of yeasts: approved standard (Vol. 22). Clinical and Laboratory Standards Institute.

Cordeiro, L., Figueiredo, P., Souza, H., Sousa, A., Andrade-Júnior, F., Barbosa-Filho, J., \& Lima, E. (2020). Antibacterial and Antibiofilm Activity of Myrtenol against Staphylococcus aureus. Pharmaceuticals (Basel, Switzerland), 13(6), 1-12. https://doi.org/10.3390/PH13060133

Dąbrowska, M., Zielińska-Bliźniewska, H., Kwiatkowski, P., Łopusiewicz, Ł., Pruss, A., Kostek, M., Kochan, E., \& Sienkiewicz, M. (2021). Inhibitory Effect of Eugenol and trans-Anethole Alone and in Combination with Antifungal Medicines on Candida albicans Clinical Isolates. Chemistry \& Biodiversity, 18(5), e2000843. https://doi.org/10.1002/CBDV.202000843

Fuentefria, A. M., Pippi, B., Lana, D. F. D., Donato, K. K., \& Andrade, S. F. de. (2018). Antifungals discovery: an insight into new strategies to combat antifungal resistance. Letters in Applied Microbiology, 66(1), 2-13. https://doi.org/10.1111/LAM.12820

Gomes, B., Neto, B., Lopes, E., Cunha, F., Araújo, A., Wanderley, C., Wong, D., Júnior, R., Ribeiro, R., Sousa, D., Medeiros, J., RCM, O., \& FA, O. (2017). Anti-inflammatory effect of the monoterpene myrtenol is dependent on the direct modulation of neutrophil migration and oxidative stress. Chemico-Biological Interactions, 273, 73-81. https://doi.org/10.1016/J.CBI.2017.05.019

Guerra, F. Q. S., Araújo, R. S. A., Sousa, J. P., Silva, V. A., Pereira, F. O., Mendonça-Junior, F. J. B., Barbosa-Filho, J. M., Pereira, J. A., \& Lima, E. O. (2018). A new coumarin derivative, 4-acetatecoumarin, with antifungal activity and association study against Aspergillus spp. Brazilian Journal of Microbiology, 49(2). https://doi.org/10.1016/j.bjm.2017.06.009

Huang, S., Tan, Z., Cai, J., Wang, Z., \& Tian, Y. (2021). Myrtenol improves brain damage and promotes angiogenesis in rats with cerebral infarction by activating the ERK1/2 signalling pathway. Pharmaceutical Biology, 59(1), 584-593. https://doi.org/10.1080/13880209.2021.1917626

Jeffery-Smith, A., Taori, S. K., Schelenz, S., Jeffery, K., Johnson, E. M., Borman, A., Manuel, R., \& Browna, C. S. (2018). Candida auris: A review of the literature. Clinical Microbiology Reviews, 31(1). https://doi.org/10.1128/CMR.00029-17

Lee, Y., Puumala, E., Robbins, N., \& Cowen, L. E. (2020). Antifungal Drug Resistance: Molecular Mechanisms in Candida albicans and Beyond. Chemical Reviews, 121(6), 3390-3411. https://doi.org/10.1021/ACS.CHEMREV.0C00199

Nikitina, L. E., Lisovskaya, S. A., Startseva, V. A., Frolova, L. L., Kutchin, A. v., Shevchenko, O. G., Ostolopovskaya, O. v., Pavelyev, R. S., Khelkhal, M. A., Gilfanov, I. R., Fedyunina, I. v., Khaliullin, R. R., Akhverdiev, R. F., Gerasimov, A. v., Abzaldinova, E. v., \& Izmailov, A. G. (2021). Biological Activity of Bicyclic Monoterpene Alcohols. BioNanoScience 2021, 1, 1-7. https://doi.org/10.1007/S12668-021-00912-8

Pappas, P. G., Lionakis, M. S., Arendrup, M. C., Ostrosky-Zeichner, L., \& Kullberg, B. J. (2018). Invasive candidiasis. Nature Reviews Disease Primers 2018 4:1, 4(1), 1-20. https://doi.org/10.1038/nrdp.2018.26

Perea, S., Gonzalez, G., Fothergill, A. W., Sutton, D. A., \& Rinaldi, M. G. (2002). In vitro activities of terbinafine in combination with fluconazole, itraconazole, voriconazole, and posaconazole against clinical isolates of Candida glabrata with decreased susceptibility to azoles. Journal of Clinical Microbiology, 40(5), 1831-1833. https://doi.org/10.1128/JCM.40.5.1831-1833.2002

Sartoratto, A., Machado, A. L. M., Delarmelina, C., Figueira, G. M., Duarte, M. C. T., \& Rehder, V. L. G. (2004). Composition and antimicrobial activity of essential oils from aromatic plants used in Brazil. Brazilian Journal of Microbiology, 35(4), 275-280. https://doi.org/10.1590/S1517-83822004000300001

Shaban, S., Patel, M., \& Ahmad, A. (2020). Improved efficacy of antifungal drugs in combination with monoterpene phenols against Candida auris. Scientific Reports 2020 10:1, 10(1), 1-8. https://doi.org/10.1038/s41598-020-58203-3

Siddiqui, Z. N., Farooq, F., Musthafa, T. N. M., Ahmad, A., \& Khan, A. U. (2013). Synthesis, characterization and antimicrobial evaluation of novel halopyrazole derivatives. Journal of Saudi Chemical Society, 17(2), 237-243. https://doi.org/10.1016/J.JSCS.2011.03.016

Tacconi, L. (2018). Scientific Methodology *. In Biodiversity and Ecological Economics. https://doi.org/10.4324/9781315096308-2

Viana, A. F. S. C., Lopes, M. T. P., Oliveira, F. T. B., Nunes, P. I. G., Santos, V. G., Braga, A. D., Silva, A. C. A., Sousa, D. P., Viana, D. A., Rao, V. S., Oliveira, R. de C. M., \& Santos, F. A. (2019). (-)-Myrtenol accelerates healing of acetic acid-induced gastric ulcers in rats and in human gastric adenocarcinoma cells. European Journal of Pharmacology, 854, 139-148. https://doi.org/10.1016/J.EJPHAR.2019.04.025

Wall, G., \& Lopez-Ribot, J. L. (2020). Current Antimycotics, New Prospects, and Future Approaches to Antifungal Therapy. Antibiotics 2020, 9, 445, 9(8), 445. https://doi.org/10.3390/ANTIBIOTICS9080445 